\title{
DAKWAH RELASI AGAMA (STUDI PRELIMINARI BERBASIS AI-QUR'AN)
}

\author{
IFTITAH JAFAR, MUDZHIRA NUR AMRULLAH \\ Universitas Islam Negeri (UIN) Alauddin Makassar \\ Email: iftitah.jafar@uin-alauddin.ac.id \\ mudzhira.nuramrullah@uin-alauddin.ac.id
}

\begin{abstract}
:
This paper reveals da'wa of interfaith relation based on the Qur'an. It is a qualitative preliminary research. The study analyzes Qur'anic verses on da 'wa through the implementation of thematic approach. The results showed that: 1. This form of da'wa is designed based on six considerations: 1. Islam is a universal religion (Q.21:107), 2. Islam promotes international communication (Q.49:13), 3. Islam acknowledges religious disparities (Q.5:48) and (Q.11:118), 4. Islam strongly emphasizes in respecting religious differences (Q.17:70). 5. Islam encourages people to live competitively (Q.5:48). 6. Qur'an encourages Muslims to be fair towards other religious followers (Q.5:8). The aim of da'wa as follows: 1. Communities understand the Qur'anic concept of interfaith relation, 2. Communities acknowledge the existence of other religions, 3. Communities may live peacefully and harmoniously. In addition, the methods of da'wa of interfaith relation, namely: 1. Religious counseling, 2. Religious dialogue, 3. Da'wa of action, and 4. Da'wa of assistance.
\end{abstract}

Keywords: Da'wa of interfaith relation, Al-Qur'an-based study

\section{PENDAHULUAN}

Relasi agama (interfaith relation) menjadi cocern utama berbagai kalangan dalam beebrapa decade terakhir. Perhatian serius ke arah relasi agama muncul karena timbulnya berbagai kasus tindakan kekerasan atas nama agama. Kekerasan atas nama agama ini antara lain dipicu oleh pemahaman yang dangkal terhadap teks-teks keagamaan. Pemahaman yang dangkal muncul sebagai akibat penggunaan pendekatan dalam memahami teks keagamaan. Pembacaan teks keagamaan dengan pendekatan atomistik yakni memahami ayat dengan memenggal bagian ayat tetentu, tanpa melihat makna keseluruhan ayat. Demikian pula jika seseorang memahami ayat tanpa memerhatikan konteks historis ayat baik makro (asbâb al-nuzûl al-âmm) maupun mikro (asbâb al-nuzûl al-khâș̣̂). Hal yang sama juga terjadi jika seseorang hanya memahami satu ayat tanpa melihat hubungannya dengan ayat-ayat lain baik dalam satu surah maupun dalam surah-surah lain. Teknik pembacaan seperti ini akan menghasilkan pemahaman radikal. Dalam kegiatan dakwahnya, dai-dai banyak menerapkan teknik pembacaan ayat seperti ini. Sebuah ayat dipenggal kemudian diterjemahkan dan diberi penjelasan dan menyimpulkan isi atau pesan ayat. Dalam cara yang sama 
sebuah ayat diterjemahkan lalu dijelaskan baik berdasarkan kitab-kitab tafsir atau dijelaskan sendiri tanpa mengaitkannya dengan ayat-ayat lain, dengan topik yang sama..

Teknik pembacaan seperti di atas menafikan analisis konteks historis dari sebuah ayat yang dikaji. Teknik ini juga tidak mempertimbangkan korelasi ayat (munâsabah). Pembacaan ayat dengan pemahaman inklusif didasarkan pada pedekatan holistik yang memadukan analisis linguistic, analisis konteks dan analisi korelasional. Berbagai pendekatan tafsir dalam memahami ayat-ayat relasi agama, seperti pendekatan sistem, pendekatan ma na cum maghzâ dan pendekatan al-'illat wa al-ma 'lùl. Penggunaan pendekatan ini akan melahirkan pemahaman ayat-ayat relasi agama dengan pemahaman inklusif. Hasil penafsiran ayat-ayat relasi agama dengan pemahaman baru membawa kepada tiga hal, pertama sikap dai dalam melihat agama dan pemeluk agama lain. Kedua mendisain metode atau pendekatan dakwah yang sesuai. Ketiga akan mengemas pesan-pesan dakwah yang sejuk yang memberi ruang apresiasi terhadap pemeluk agama lain.

Tulisan ini memperkenalkan salah satu bentuk dakwah baru yakni dakwah relasi agama. Tulisan ini akan mencoba menjawab pertanyaan bagaimana bentuk dakwah relasi agama? Pembahasan mengikuti sistimatika sebagai berikut: makna dakwah relasi agama, tujuan dakwah relasi agama, dan metode dakwah relasi agama, dan penutup.

\section{PEMBAHASAN}

\section{Makna Dakwah Relasi Agama}

Seiring dengan perkembangan ilmu pengetahuan dan teknologi, dakwah juga turut berkembang. Perkembangan dakwah ini sebagai akibat persentuhannya dengan dengan berbagai ilmu pengetahuan dan kajian. Munculnya varian bentuk dakwah baru menjadi salah satu indikator perkembangan ini. Bentuk-bentuk dakwah baru ini diformulasi berdasarkan antara lain: pesan, metode dan tujuan pelaksanaannya. Dakwah relasi agama dibentuk berdasarkan salah satu tujuan dakwah universal yaitu mewujudkan persaudaraan kemanusiaan. Dakwah relasi agama digagas sebagai respon terhadap konflik horizontal bernuansa agama yang terjadi di berbagai belahan dunia termasuk di Indonesia. Indonesia mencatat beberapa kasus konflik bernuansa SARA, seperti di Kupang, Ambon, Poso dan Papua. Dakwah relasi antara lain dipahami dengan penyampaian konsep dan pesan Islam tentang relasi agama untuk mewujudkan masyarakat yang toleran, harmonis dan damai. Pesan-pesan dakwah ini didasarkan pada hasil penafsiran mufassir modern dan kontemporer dengan menggunakan pendekatan tafsir baru, seperti hermeneutika. Pendekatan tafsir ini dikemas sesuai dengan trend baru dalam kajian relasi agama. 


\section{Landasan Pemikiran Dakwah Relasi Agama}

\section{Landasan Textual}

Dakwah relasi agama ditegakkan di atas fundasi yang kokoh:

\subsection{Islam sebagai agama universal $(\mathbf{Q . 3 4 : 2 8 )}$}

Sebagai agama universal, Islam tidak terbatasi oleh sekat-sekat waktu dan tempat. Ini berarti Muslim mengemban amanah untuk menyampaikan dan menyebarkan ajaran Islam ke seluruh pelosok dunia, memberikan kabar gembira dan peringatan, sebagai amanah yang diwariskan dari utusan Allah, Muhammad saw. Untuk mengemban tugas suci ini tentunya umat Islam harus mengenal lebih dekat umat lain sebagai sasaran dakwah. Tujuannya untuk memudahkan dalam menyampaikan pesan-pesan Ilahi kepada mereka. Di samping itu, umat Islam tentunya harus menguasai pesan-pesan dakwah dengan baik, demikian pula metode penyampaian dan media yang digunakan.

\subsection{Islam menekankan komunikasi internasional (Q.49:13)}

Disparitas etnis, ras, suku, dan bangsa mengandung suatu hikmah yang dalam yaitu agar mereka terlibat dalam komunikasi. Namun di sini tidak hanya sekedar berkomunikasi melainkan terjadi proses belajar dan sharing antara satu dengan yang lain. Kalau ini terjadi berarti setiap bangsa akan mempunyai wawasan yang luas dan dalam. Suatu suku akan mempelajari dan mengadopsi hal-hal yang baik daik dari suku lain dan menawarkan halhal positif yang mereka miliki, jadi terjadi take and give.

\subsection{Islam mengenal dan mengakui disparitas agama (Q.5:48)}

Disparitas agama adalah sunnatullah. Kalau Tuhan menghendaki semua manusia hanya akan menganut satu agama. Akan tetapi Tuhan menciptakan banyak agama sebagai jalan hidup sesuai dengan komunitas yang dihadapi rasul-rasul yang diutus. Pesan dakwah dalam bentuk pengakuan dan penghargaan terhadap agama lain memang perlu didakwahkan kepada umat Islam. Tujuannya adalah agar umat Islam dapat mengakui dan menghargai agama lain.

\subsection{Islam menekankan perlunya menghargai perbedaan agama (Q.17:70)}

Perbedaan agama adalah suatu realitas yang tak terbantahkan. Perbedaan antara lain bisa dilihat dalam lima hal: 1. Konsep ketuhanan, 2. Sistem ibadah, 3. Kitab suci, 4. Alat agama, dan 5. Institusi keagamaan. Merespon perbedaan tersebut, Ilmu Perbandingan Agama mewariskan semboyan "agree in disagrrement" artinya setuju dalam perbedaan.

1.5 Islam mendorong manusia untuk dapat hidup secara kompetitif (Q.5:48)

Islam meyakini hidup sebagai perjuangan atau jihad. Menuntut ilmu merupakan salah satu manifestasi jihad. Bahkan kemampuan mengontrol 
dan mengendalikan hawa nafsu dinilai sebagai jihad paling besar. Dalam hubungannya dengan dakwah relasi agama, seorang Muslim hendaknya didorong untuk dapat memahami dan menempatkan jihad dalam proporsi yang benar. Memerangi dan menyerang agama lain dalam tanpa sebab dalam kondisi damai bukanlah jihad.

\subsection{Islam mendorong penganutnya untuk tetap bersikap dan berlaku adil terhadap penganut agama lain $(\mathbf{Q . 5 : 8 )}$.}

Sikap adil merupakan sesuatu yang dikenal baik secara universal ( $m a$ 'rûf). Sikap adil tidak boleh terhalang hanya karena perbedaan keyakinan, ideologi dan budaya. Keadilan seyogyanya ditegakkan kepada siapa saja tanpa melihat latar belakang mereka. Bagi Muslim sikap dan perilaku adil menjadi salah satu jalan pinats menuju ketaqwaan. Dalam kaitannya dengan dakwah relasi agama, Muslim hendaknya senantiasa dimotivasi melalui dakwah agar tetap konsisten dalam berlaku adil kepada siapa saja dan kapan saja.

\section{Landasan Faktual}

Dalam lima tahun terakhir ini terjadi tensi dalam hubungan antar agama di Indonesia. Terutama hubungan antar Islam dan Kristen, terlebih lagi dalam suasana perpolitikan, dengan adanya pemilihan presiden dan pemilihan legislatif (17 April 2019). Indikator buruknya hubungan kedua agama ini adalah semakin banyaknya kasus penistaan agama. Ironisnya penistaan agama ini pada umumnya dilakukan oleh penganut agama Kristen. Sebagian di antara kasus penistaan ini telah menyeret pelakunya dalam penjara, seperti Basuki Tjahaya Purnama (Ahok) dan Pdt. Saifuddin Ibrahim. Hingga saat ini ekspresi penghinaan, kebencian dan kririkan tajam terhadap agama Islam dengan berbagai dimensinya semakin marak di media sosial.

Salah satu penyebab fenomena ini adalah eksklusifitas dalam beragama yang antara lain ditandai dengan ketidakpahaman terhadap agama lain, sikap apriori terhadap agama lain, dan ketiadaan pengakuan dan penghargaaan terhadap agama lain. Hugh Goddard, dosen teologi, Universitas Notingham, setelah mengamati hubungan antara Muslim dan Nashrani, mengakui bahwa level saling memahami (mutual understanding) antara kedua komunitas agama ini terkadang sangat rendah bahkan dapat dikatakan bahwa justeru saling tidak memahami (mutual ignorance) jauh lebih tersebar ketimbang saling memahami. ${ }^{1} \quad$ Signifikansi dakwah relasi agamanya adalah umat Islam diharapkan tidak mudah terpancing dan terprovokasi dalam merespon ujaran kebencian, penghinaan non-Muslim terhadap Islam. Sebab kalau hal ini terjadi

1 Hugh Goddard, Christian and Muslim: From Double Standard to Mutual Understanding (Richmond, Surrey: Curson Press, 1995), h. 1. 
maka akan memicu konflik atas nama agama yang tentunya akan merugikan kedua belah pihak. Sikap sabar, tabah dan menyerahkan kasusnya kepada pemerintah seperti yang ditunjukkan umat Islam selama ini kiranya menjadi pembelajaran berharga bagi non-Muslim.

\section{Tujuan Dakwah Relasi Agama}

Setiap bentuk dakwah pasti memiliki tujuan tersendiri. Dakwah relasi agama sebagai suatu bentuk dakwah terbaru didisain dengan tujuan sebagai berikut:

\section{Masyarakat Memahami Konsep Relasi Agama dalam Al-Qur'an}

Sejarah agama mencatat bahwa pemeluk suatu agama hanya cenderung memahami diri mereka sendiri tanpa berusaha memahami pemeluk agama lain yang ada di sekitarnya. Dalam hubungan antar agama pemeluk suatu agama, biasanya tebagi dua. Pertama, mereka yang hanya memerhatikan orang-orang yang seagama atau sekeyakinan dengan mereka. Kelompok ini rentan dengan konflik bernuansa SARA dengan kelompok atau pemeluk agama lain. Kedua, mereka yang terbuka dengan pemeluk agama lain, bahkan bergaul dan bekerjasama dengan mereka. Kelompok ini melahirkan komunitas yang saling menghargai dan menghormati sehingga mereka tampak toleran dan harmonis. Dakwah dengan berdasar pada pemahaman dan penafsiran inklusif ayat-ayat relasi agama mendorong terwujudnya masyarakat yang mampu memahami posisi kelompok atau pemeluk agama lain.

Konsep relasi agama didasarkan pada penafsiran inklusif terhadap ayatayat relasi agama. Pemaknaan dan pemahaman terhadap ayat-ayat relasi agama sangat terkait kecenderungan hubungan antar agama. Di saat hubungan antar agama mengalami tensi dan ketegangan akibat benturan, gesekan bahkan konflik pemaknaan dan pemahaman ayat-ayat relasi agama juga cenderung konfrontatif. Sebaliknya di saat hubungan antar agama harmonis maka pemaknaan dan pemahaman ayat-ayat relasi agama juga cenderung inklusif dan akomodatif. Kalau dijumpai pemahaman ayat-ayat relasi agama lebih tegas bahkan cenderung ofensif di zaman Nabi Muhammad saw. antara lain disebabkan karena Islam sebagai agama baru berada dalam posisi pembentukan identitas agar berbeda dengan agama lain, khususnya Yahudi dan Nashrani. Di saat terjadi perang, atau umat Islam mengalami penyerangan dalam berbagai bentuknya maka ayat-ayat relasi agama cenderung dipahami lebih konfrontatif. Dewasa ini, meskipun di beberapa belahan dunia masih sering terjadi konflik antar agama, namun secara umum diperoleh indikasi kecenderungan untuk hidup berdampingan secara damai. Globalisasi memang mendorong terciptanya hubungan dan kerjasama antar bangsa, yang dengan sendirinya akan melibatkan orang-orang dengan latar belakang keyakinan yang berbeda. 
Menariknya justeru kesadaran perlunya mempererat hubungan antar agama ini awalnya muncul di Barat. Konsep-konsep hubungan antar agama banyak digagas pakar dan pemikir Barat. Salah satu semboyan yang sering dikutip dalam kajian hubungan antar agama adalah pernyataan Hans Kung "There will be no peace among the nations without peace among religions. There will be no peace among the religions without dialogue among the religions." Artinya: Tidak akan terwujud perdamaian antara bangsa-bangsa tanpa adanya perdamaian antara agama-agama. Tidak akan tercipta perdamaian antara agama-agama tanpa adanya dialog antara agama-agama. Amerika sebagai salah satu negara multicultural merasakan perlunya dialog di antara para pemeluk agama yang berbeda. Gagasan relasi agama ini kemudian direspon, dipelajari dan dianalisis pemikir Muslim yang mengantar mereka untuk mencoba melihat kembali penafsiran ayat-ayat relasi agama. Pemahaman baru terhadap ayat-ayat relasi agama, misalnya terwakili dalam karya Fazlur Rahman, Mahmoud Ayoub, Hossein Nashr, dan Muhammad Syahrur.

Dengan diterbitkannya sebuah dokumen "A Common Word Between Us and You" (ACW), 2007, Amin Abdullah menilai bahwa untuk mendapatkan toleransi dalam relasi agama umat Islam harus membaca Al-Qur'an dengan cara baru dan lebih segar. Abdullah sendiri menawarkan pendekatan sistem (system approach), sebagai suatu cara baru yang menghindari cara baca berbasis penggantian atau pembatalan fungsi ayat (naskh). ${ }^{2}$ Pendekatan ini diadopsi dari kajian ushul fiqhi yang diintrodusir oleh Jasser Auda ( 2008). Syamsuddin juga berkontribusi dengan menawarkan pendekatan " $m a$ 'na cum maghza" dalam pembacaan ayat-ayat relasi agama, khususnya Q.2:111-113. ${ }^{3}$ Ma 'na di sini dipahami dengan melihat kembali konteks historis ayat di saat diwahyukan sedangkan maghzâ adalah signifikansi ayat relasi agama dalam konteks kekinian.

Ayat-ayat kitab suci berbasis klaim kebenaran dipastikan harus mendapatkan perhatian khusus. Pemahaman eksklusif terhadap ayat-ayat dimaksud menjadi pemicu konflik. Rumpun agama samawi sebagai agama misi dipastikan akan mendakwahkan keyakinan agamanya berdasarkan konsep kitab suci mereka. Umat Yahudi mengklaim bahwa kaum Nashrani tidak mengikuti agama yang benar (Q.2:111), dan mereka tidak mungkin masuk

${ }^{2}$ Amin Abdullah, "Sistem Approach" dalam Suhadi (ed.), COSTLY TOLERANCE:

Tantangan Baru Muslim-Kristen di Indonesia dan Belanda (Yogyakarta: CRCS (Center for Religious and Cross-Cultural Studies), Program Studi Sgama dan Lintas Agama. Sekolah Pascasarjana Lintas Disiplin, Universitas Gadjah Mada, 2015), h. 7.

${ }^{3}$ Sahiron Syamsuddin, "Ma'na Cum Maghza" dalam Suhadi (ed.), COSTLY

TOLERANCE, h. 67. 
Syurga (Q.2:113). Umat Kristiani, sebaliknya, juga mengklaim bahwa kaum Yahudi tidak mengikuti agama yang benar (Q.2:111), dan mereka mustahil akan masuk Syurga (Q.2:113). Umat Islam juga mengklaim bahwa hanya Islamlah agama yang diterima di sisi Allah (Q.3:85). Di ayat ini bahkan ditegaskan bahwa pemilihan agama selain Islam akan berdampak kerugian di hari kemudian.

Selain gagasan relasi agama orang-orang Barat juga mencoba memahami konsep-konsep Al-Qur'an untuk konteks tertentu. John Parinder, misalnya menulis buku Jesus in the Qur'an, demikian pula Karel Steenbrink ${ }^{4}$ menulis dalam judul yang sama. Meskipun awalnya buku ini dimaksudkan sebagai upaya bagaimana Al-Qur'an memotret Yesus untuk mendapatkan justifikasi Al-Qur'an, namun dipastikan karya ini bisa dipahami dengan suatu upaya mendekatkan antara Islam dan Kristen. Setidaknya menjembatani dua keyakinan yang berbeda. Penafsiran eksklusif terhadap ayat-ayat relasi agama mulai dikritik bahkan ditolak. Pemahaman ayat yang menyudutkan agama lain perlu ditinjau ulang, ayat-ayat yang secara tekstual memosisikan agama lain tidak proporsional perlu dilakukan reinterpretasi, agar lebih inklusif.

Sebagai contoh, QS. al-Fatihah (1): 7, dalam tafsir-tafsir klasik bahkan modern, "al-maghdhub" ditafsirkan dengan orang-orang Yahudi dan "alZhâllîn" dengan orang-orang Nashrani. Terhadap penafsiran ayat ini pengkaji terbagi dua, sebagian mempertahankan dengan dasar disebutkan dalam hadits. Bagi mereka yang perlu dipahami adalah alasan kenapa orang-orang Yahudi mendapatkan murka Tuhan dan orang-orang Nashrani dianggap sebagai orang-orang sesat. M. Quraish Shihab menyebutkan beberapa pelanggaran yang dilakukan orang-orang Yahudi yang mengakibatkan mendapatkan murka yaitu: ${ }^{5}$ 1. Mengingkari tanda-tanda kebesaran Ilahi, 2. Membunuh nabi-nabi tanpa alasan yang benar, 3. Iri hati atas anugerah Allah kepada orang lain, 4. Membantah keterangan-keterangan Rasul, 5. Meyekutukan Allah dan mempersonifikasi Tuhan dengan sapi, 6. Melakukan pelanggaran dalam bentuk penyuapan. 7. Penyalahgunaan kekuasaan dan lain-lain. Sebagian lain, terutama penggiat relasi agama memandang tafsir tersebut tidak bisa dipertahankan karena menyudutkan pemeluk agama lain. Teks Al-Qur'an sendiri tidak menyebutkan seperti itu, hanya penafsiran dan pemahaman mufassir terhadap ayat. Pemahaman egaliter dan inklusif adalah "al-

${ }^{4}$ Professor emeritus Teologi Lintas Budaya, di Universitas Utrecht. Dia lahir di Breda, Belanda 16 Januari 1942. Dia menulis beberapa buku sejarah Islam di Indonesia, seperti: Pesantren, Madrasah dan Sekolah: Pendidikan Islam dalam Kurun Modern; Beberapa Aspek tentang Islam di Indonesia Abad ke 19; Kaum Kolonial Belanda dan Islam di Indonesia 15961942).

5 M. Quraish Shihab, Tafsir al-Mishbah: Pesan, Kesan dan Keserasian Al-Qur'an, Vol.1 (Jakarta:Penerbit Lentera Hati, 2000), h. 72. 
maghdhûb" mereka yang dimurkai, tanpa menyebutkan label agama tertentu, jadi siapa saja, yang telah mendapat amarah Tuhan. Quraish Shihab juga menyebutkan beberapa contoh pelanggaran yang berefek kemurkaan Tuhan, yaitu: ${ }^{6}$ 1. Membunuh seorang mukmin dengan sengaja tanpa alasan yang benar, 2. Berperasangka buruk kepada Tuhan dan meragukan pertolonganNya, 3. Lari dari peperangan (perjuangan) membela kebenaran, 4. Memilih kekufuran dan menentang ajaran agama yang benar, 5. Perzinahan seorang wanita yang masih terikat dengan perkawinan sah.

Kenapa orang-orang Nashrani dianggap sebagai orang-orang yang sesat. Berdasarkan analisis penulis terhadap ayat-ayat Al-Qur'an mengenai Ahli Kitab diperoleh informasi kesesatan mereka, antara lain: 1. Mereka melampaui batas dalam agama (Q.4:171). Salah satu contoh dalam hal ini adalah menjadikan Nabi Isa as. sebagai Tuhan. Yesus tidak pernah mengklaim dirinya sebagai Tuhan. 2. Mereka mengingkari ayat-ayat Allah (Q.3:99). 3. Mereka menghalang-halangi orang ke jalan Allah (Q.3:99). 3. Mereka mengimani sebagian kitab dan mengingkari sebagian yang lain (Q.2:85). 4. Mereka berbeda pendapat tentang agama Ibrahim, padahal Tawrat dan Injil diturunkan sesudah masa Ibrahim (Q.3:65). 5. Mereka mengingkari kenabian Muhammad, padahal mereka menyaksikan bukti kebenaran. 6. Menambahkan sesuatu pada agama yang tidak diajarkan Allah dan Rasul-Nya. 7. Mengatakan sesuatu yang tidak benar atas nama agama Allah. 8. Mengatakan bahwa Tuhan itu trinitas, padahal itu dusta. Beberapa alasan inilah yang menempatkan orang-orang Nashrani sebagai orang-orang sesat.

Bagi kelompok kedua, terma "al-zhâllî" dipahami dengan mereka yang tersesat dari dari jalan Tuhan, tanpa merefer ke pemeluk agama tertentu, jadi siapa saja dianggap sesat oleh Tuhan. Hanya Tuhan yang mampu mengetahui siapa yang tersesat dan siapa yang terpetunjuk (Q.16:125). Berdasarkan analisis penulis terhadap ayat-ayat Al-Qur'an diperoleh informasi mengenai siapa yang dimaksud dengan orang-orang sesat (al-zhâllîn) diantaranya: 1. Orang-orang yang ingkar sesudah beriman, kemudian bertambah kekafirannya (Q.3:90). 2. Orang-orang yang tidak mendapatkan petunjuk dari Allah (Q.6:77). 3. Orang-orang yang berputus asa dari rahmat Tuhan (Q.15:56). Beberapa tipe orang-orang sesat ini tidak dikaitkan dengan kelompok pemeluk agama tertentu.

Terma-terma relasi agama dalam ayat-ayat Al-Qur'an, seperti: al-qitâl, aljihâd dan lain-lain diteliti kembali kemudian ditafsirkan berdasarkan

${ }^{6}$ M. Quraish Shihab, Tafsir al-Mishbah, Vol.1, h. 72. 
kecenderungan hidup beragama secara universal. Pemahaman kontemporer term-terma ini menjadi concern tersendiri mufassir modern dan kontemporer.

Dengan demikian terjadi pergeseran penafsiran sesuai tuntutan, dan hal ini lumrah. Penafsiran memang relatif, mengikuti perkembangan dan pergumulan hidup masyarakat. Hasil-hasil penafsiran baru yang dinilai lebih terbuka dan lebih akomodatif terhadap agama lain menjadi materi pesan utama dalam dakwah relasi agama. Diakui dan disadari memang bahwa penafsiran baru ini tidak serta merta dan sepenuhnya dapat diterima semua lapisan umat Islam secara langsung, dibutuhkan waktu yang lama untuk meyakinkan orang. Namun demikian, diperlukan komitmen yang kuat untuk tetap mendakwahkannya karena bertujuan mulia dan menjadi tuntutan masyarakat global.

\section{Masyarakat Bersikap Terbuka dan Mengakui Eksistensi Agama Lain}

Sering terjadi pemeluk suatu agama memosisikan diri mereka secara eksklusif. Eksklusifitas beragama berimbas antara lain pada sikap kurang atau tidak memerhatikan kelompok atau pemeluk agama lain. Sikap ini akan berekses pada klaim kebenaran bahwa hanya keyakinan agama merekalah yang benar yang lainnya salah. Ujung atau klimaks dari sikap ini menganggap kelompok agama lain sebagai kafir yang wajib diperangi. Inti sikap ini adalah penolakan terhadap agama lain. Dakwah relasi agama mengantar masyarakat untuk belajar untuk lebih terbuka, lebih inklusif dan egalitarian. Dakwah relasi agama akan membimbing masyarakat bagaimana memosisikan diri di antara kehadiran pemeluk agama lain yang juga eksis dan diakui keberadaannya secara resmi oleh negara. Mereka itu mempunyai hak yang sama dengan warga negara lainnya dalam bingkai Negara Kesatuan Republik Indonesia (NKRI). Kegagalan dalam menempatkan diri pada posisi yang tepat akan memicu konflik. Tujuan dakwah akan tercapai jika diarahkan pada upaya meredam pemicu konflik. Pemicu konflik antara lain diskriminasi ke akses sumber daya ekonomi, kesenjangan secara ekonomi, dan dampak percaturan kehidupan politik.

Dalam relasi dengan kelompok non-Muslim, sikap Al-Qur'an sejatinya kontekstual. Sikap Al-Qur'an terhadap non-Muslim tergantung pada sikap mereka terhadap umat Islam. Secara kategoris, Al-Qur'an menunjukkan tiga sikap: positif, netral, dan negatif. ${ }^{7}$ Sikap positif misalnya tergambarkan ketika Al-Qur'an menyatakan umat Nashrani sebagai mereka yang paling akrab persahabatnnya dengan orang-orang Islam (Q.5:82). Sikap netral, misalnya

${ }^{7}$ Muhammad Ali, "Hermeneutika Kontekstual dan Pluralisme Agama" dalam TEOLOGI PLURALIS-MULTIKULTURAL: Menghargai Kemajemukan Menjalin Kebersamaan (Jakarta: Penerbit Buku Kompas, 2003), h. 24-25. 
ditunjukkan Al-Qur'an ketika menyatakan bahwa Tuhanlah yang akan memutuskan secara adil terhadap semua perselisihan agama dan kelompok di dunia ini. (Q.13:17). Adapun sikap negatif ditunjukkan dalam konteks bahwa sebagian Ahli Kitab merubah kitab suci untuk kepentingan mereka, berlebihlebihan dalam agama atau menunjukkan permusuhan dan pengkhianatan terhadap komunitas muslim.

\section{Masyarakat Hidup Berdampingan dengan Pemeluk Agama Lain Secara Harmonis dan Damai}

Dakwah relasi agama bukan hanya sampai pada tahap dimana seseorang dapat mengakui eksistensi agama lain dan bagaimana menempatkan diri di tengah-tengah penganut agama lain, tetapi bagaimana seseorang dapat berinteraksi dengan kelompok atau pemeluk agama lain. Salah satu ukuran efektivitas dakwah relasi agama adalah terwujudnya komunitas yang saling peduli dan bekerjasama dalam program-program kemasyarakatan. Inilah tujuan sebenarnya dari dakwah relasi agama, yang tidak berhenti hanya pada level pengakuan dan level hidup berdampingan, melainkan pada perilaku dalam interaksinya dengan pemeluk agama lain. Bentuk nyata tujuan ketiga ini antara lain: 1. Saling membantu dalam pelaksanaan acara-acara keagamaan. Pada wilayah tertentu, praktek kehidupan beragama semacam ini sudah hal yang biasa. Koran sering menampilkan berita pemuda muslim membantu pengamanan perayaan natal, dan sebaliknya pemuda Kristen membantu pengamanan kegiatan perayaan hari-hari besar Islam, seperti lebaran.

Tradisi ini menjadi modal utama dalam merajut kebersamaan dalam bingkai kebangsaan dan kemanusiaan. Masyarakat yang tetap menjaga dan memelihara tradisi ini biasanya hidup damai dan jauh dari konflik. 2 . Kerjasama dalam kegiatan kemasyarakatan. Masyarakat dengan latar belakang agama yang berbeda secara bersama-sama melibatkan diri dalam proyek kemasyarakatan, seperti kebersihan, oleh raga, dan keamanan. 3. Berpartisipasi bersama kelompok agama lain dalam menyukseskan programprogram pemerintah. Program-program yang diluncurkan pemerintah dipastikan melibatkan masyarakat. Tanpa keterlibatan masyarakat programprogram pemerintah mustahil akan berhasil sesuai yang diharapkan. Di sinilah partisipasi aktif berbagai lapisan masyarakat tanpa melihat latar belakang etnis, suku dan keyakinan agamanya.

\section{Bentuk-bentuk Dakwah Relasi Agama}

Beragam format dakwah relasi agama yang dapat dilakukan namun tentunya sangat terkait wilayah di mana dakwah akan disampaikan. Hanya saja 
berdasarkan pengalaman terhadap konflik-konflik yang terjadi di Indonesia, agaknya bentuk-bentuk dakwah berikut dapat dipertimbangkan.

\section{Penyuluhan Agama}

Secara epistemologis terma "penyuluhan" merupakan terjemah dari kata Bahasa Inggris "counseling." Dalam Collins Co-build English Language Dictionary disebutkan "counselling is the activity of giving people advice as part of your job, ${ }^{8,}$ artinya counseling adalah aktivitas pemberian nasihat kepada orang-orang sebagai bagian tugas anda." Counseller berarti "a person whose job is to give advice to people who need it," ", artinya counseller adalah seseorang yang pekerjaannya memberikan nasihat kepada orang-orang yang memerlukannya. Dalam Bahasa Indonesia penyuluhan berarti penerangan, yakni menerangkan segala sesuatu yang terkait dengan agama, seperti: halal dan haram, ibadah, pernikahan dan keluarga sakinah, zakat, kemasjidan dan lain-lain.

Tugas ini sebetulnya merupakan kegiatan yang sudah melekat pada diri seorang dai, baik yang berasal dari lembaga dakwah maupun individu. Penyuluh idealnya perlu memfokuskan diri pada topik-topik tertentu karena mereka merupakan aparat pemerintah, dengan sendirinya penerangan dan nasihat dakwahnya diarahkan pada program-program pemerintah dalam pembinaan kehidupan beragama. Penyuluh agama sejatinya memberikan penerangan mengenai program-program pemerintah melalui bahasa agama. Tujuannya antara lain adalah meningkatkan peran dan kontribusi umat Islam dalam pembangunan nasional. Tema-tema sentral berubah sesuai dengan arah gerak pembangunan nasional di bidang keagamaan. Tema-tema kajian antara lain: 1. Hak-hak asasi manusia, 2. Kesetaraan Gender, 3. Relasi antar agama, 4. Resolusi konflik, khususnya konflik bernuansa SARA, 5. Sistim politik Islam, 6. Ekonomi dan bisnis Islam, dan 7. Sekte dan sempalan agama.

Fungsi penyuluhan agama: 1. Fungsi konsultatif, yakni penyuluh agama memosisikan diri sebagai penyampai penerangan agama kepada masyarakat. Fungsi konsultatif, yakni penyuluh agama menempatkan dirinya sebagai problem solver yang membantu masyarakat mengatasi masalah yang dihadapi. 2. Fungsi edukatif, yakni penyuluh agama mendidik masyarakat dengan sebaik-baiknya sesuai ajaran agama. Penyuluh agama memberikan pencerahan keagamaan kepada umat atas nama pemerintah. 3. Fungsi advokatif, yakni penyuluh agama memiliki tanggung jawab moral dan sosial

\footnotetext{
${ }^{8}$ John Sinclair (ed.), Collins Co-build English Language Dictionary (London: William Collins Sons and Co. Ltd, 1987), h. 321.

${ }^{9}$ John Sinclair (ed.), Collins Cobuild English Language Dictionary, h. 321.
} 
memberikan pembelaan kepada masyarakat atas berbagai ancaman dan gangguan yang merugikan dalam segenap dimensi agama.

Kegiatan penyuluhan menempati posisi strategis dalam kehidupan masyarakat. Penyuluhan biasanya dikaitkan dengan hajat kebutuhan dasar masyarakat. Dalam kepenyuluhan di Indonesia sepanjang sejarahnya kita mengenal beberapa bentuk, seperti: peyuluhan kesehatan, penyuluhan keluarga berencana, penyuluhan hukum, penyuluhan pertanian dan penyuluhan agama. Penyuluhan agama agaknya menjadi perhatian khusus karena selain kegiatan dakwah secara umum juga dikenal penyuluhan agama secara khusus. Di Perguruan tinggi agama, misalnya di UIN Alauddin Makassar adalah jurusan atau prodi khusus untuk penyuluhan agama yaitu Jurusan Bimbingan dan Penyuluhan Agama (BPI). Kementerian agama RI. juga memberi perhatian khusus pada kegiatan penyuluhan agama.

Ada dua jenis penyuluh agama yang bekerja di tengah-tengah masyarakat: 1. Tim penyuluh agama PNS. Dasar pelaksanaan adalah Surat Keputusan Menteri Agama RI. Nomor: 516, Tahun 2003 tentang Petunjuk Teknis Pelaksanaan Fungsional Penyuluh Agama dan Angka Kreditnya, tanggal 4 November 2003. Bab II ketentuan umum penyuluh, bahwa yang dimaksud dengan "Penyuluh Agama" adalah pegawai negeri sipil yang diberikan tunjangan, tanggung jawab dan wewenang secara penuh oleh pejabat yang berwenang untuk melakukan kegiatan bimbingan keagamaan dan penyuluhan pembangunan melalui bahasa agama. 2. Penyuluh agama nonPNS. Landasan operasionalnya adalah Keputusan Direktorat Jenderal Bimbingan Masyarakat Islam, Nomor: DJ.III/432 Tahun 2016, tentang Petunjuk Teknis Pengangkatan Penyuluh agama non-PNS. Penyuluh agama Islam non-PNS adalah pegawai pemerintah dengan yang diangkat, ditetapkan dan diberi tunjangan jawab serta wewenang secara penuh untuk melaksanakan kegiatan bimbingan, penyuluhan melalui bahasa agama, pembangunan pada masyarakat melalui surat keputusan kepala kantor kementerian agama kota/kabupaten.

Kegiatan penyuluhan dalam berbagai aspek kehidupan masyarakat sangat diperlukan. Pelanggaran hukum terjadi mungkin disebabkan karena lemah dan sangat terbatasnya sosialisasi hukum dan perarutran-peraturan pemerintah. Terdapatnya sampah-sampah di berbagai tempat yang tidak selayaknya, juga indikator kurang atau lemahnya penyuluhan kesehatan dan kebersihan. Gagal atau berkurangnya hasil panen petani karena penyakit tanaman yang tidak bisa diatasi, juga menjadi bukti tidak ada atau kurangnya penyuluhan pertanian. Terjadinya gangguan masyarakat, meningkatnya pencurian, meningkatnya kekerasan seksual dan lain-lain menjadi sinyal tidak atau kurang tersentuhnya masyarakat dengan penyuluhan agama. Agaknya 
diperlukan kegiatan penyuluhan terpadu yang melibatkan tim penyuluh dari berbagai instansi sesuai masalah yang dihadapi masyarakat.

Kegiatan penyuluhan ini melibatkan dai secara umum atau dai dari penyuluh agama pemerintah. Sebaiknya melibatkan para penyuluh di bawah koordinasi kementrian agama karena mereka membawa panji-panji negara. Negara sendiri bertanggung jawab dalam pembinaan masyarakat untuk menciptakan masyarakat damai dan sejahtera. Dai untuk keperluan ini bisa bekerjasama dengan tim penyuluhan lain seperti penyuluhan: hukum, kesehatan dan pertanian. Mereka bisa berkolaborasi mendisain suatu program dimana penyuluhan dengan berbagai perspektifnya bisa dilakukan dalam suatu acara terjadwal. Dai penyuluh ini dekat dengan masyarakat bahkan selayaknya senantiasa berada di tengah-tengah masyarakat berperan sebagai konsultan agama. Karena dekat dengan masyarakat sehingga dai penyuluh ini dapat dengan mudah mendapatkan umpan balik dari masyarakat.

Penyuluh agama ini dalam mengemban tugas dihadang dengan berbagai masalah. Masalah dimaksud antara lain: 1. Keterbatasan ilmu agama sesuai dengan perkembangan masyarakat. Penelitian Samiang Katu, menguatkan sinyalemen ini, dimana berdasarkan pengakuan penyuluh bahwa mereka merasakan kurang dan terbatasnya ilmu mereka sehingga mereka menganggap perlunya mengupdate ilmu mereka. ${ }^{10}$ Dalam hubungannya dengan relasi agama, penyuluh agama harus memahami kecenderungan hubungan antar pemeluk agama dewasa ini. Disamping itu mereka juga harus memahami penafsiran baru ayat-ayat relasi agama agar tidak terjebak pada penafsiran lama yang sudah tidak sesuai. Sebagai tambahan, mereka juga harus melengkapi diri dengan berbagai ilmu penunjang seperti: Komunikasi nir-kekerasan, Komunikasi antar pribadi, komunikasi lintas agama dan budaya dan prinsip-prinsip dakwah inklusif, meningkatkan kemampuan komunikasinya agar pesan-pesan yang disampaikan bisa efektif. 2 . Munculnya masalah-masalah baru dalam agama yang dirasakan sulit untuk diberi solusi. Penelitian Samiang katu menunjukkan pengakuan tulus dari respondennya bahwa mereka mengalami kesulitan menghadapi masalah keagamaan baru, seperti adanya mesjid yang tidak merayakan mawlid nabi Muhammad saw. karena dianggap bid'ah. ${ }^{11}$

\section{Dialog Antar Agama}

${ }^{10}$ Samiang Katu, "Penyuluh Agama dan Pembumian Al-Qur'an," Jurnal al-Adyaan, Vol. I Nomor 2, Desember 2015: 1-21.

${ }^{11}$ Samiang Katu, "Penyuluh Agama dan Pembumian Al-Qur'an," Jurnal al-Adyaan, Vol. I Nomor 2, Desember 2015: 1-21. 
Secara internasional dalam komunitas Muslim, dialog antar umat beragama diinisiasi oleh Muktamar al-Alam al-Islami (World Muslim Congress), yang didirikan 1926. Pada 1969 Sekretaris Jenderal, Imanullah Khan, sudah mengangkat isu dialog antar umat beragama, khususnya dengan Kristen. ${ }^{12}$ Untuk kasus Indonesia, 1967 menjadi tonggak sejarah dialog antar umat beragama yang diprakarsai Departemen Agama, yang dipimpin Menteri Agama, K.H.M. Dachlan. Musyawarah antar agama dilaksanakan di Jakarta 30 November 1967 atas prakarsa pemerintah. Pertemuan dipimpin oleh Menteri Agama dan dihadiri sekitar 20 tokoh Muslim, Protestan dan Katolik. Musyawarah ini dilakukan sebagai respon atas ketegangan dan konflik agama yang terjadi di berbagai wilayah di Indonesia sebagai akibat dari penyebaran agama. $^{13}$

Dialog antar pemeluk agama juga menjadi pilihan dalam dakwah relasi agama di era global. Kita sepenuhnya percaya bahwa kita dapat dan mesti belajar dari keyakinan-keyakinan orang lain, "dialog" bahkan dengan mudah dapat menjadi strategi konversi agama. Pluralitas keyakinan, sebagai karakteristik terdefinisikan bagi spiritualitas abad 21, menuntut bahwa semua tradisi etika-religi memasuki dialog antar peradaban untuk saling belajar. Dengan dialog dan komunikasi antar agama setidaknya membantu peserta dialog dalam memahami interpretasi dan respon masing-masing terhadap sensasi keberagamaan. Keseluruhan elemen komunikasi dalam model komunikasi manusia klasik yang dijabarkan ke dalam delapan elemen oleh Taylor sesungguhnya memberi kontribusi dalam dialog atau komunikasi. ${ }^{14}$ Kajian Komunikasi antar agama seharusnya melampaui langkah saat ini yang hanya cenderung membandingkan karakteristik unik dari agama-agama yang berbeda kepada langkah mengkaji dan mempromosikan secara sistimatis dialog dan komunikasi antar agama.

12 J. B. Banawiratma, Zainal Abidin Bagir (ed.), Dialog Antar Umat Beragama (Gagasan dan Praktik di Indonesia), (Yogyakarta: Program Studi Agama dan Lintas Budaya, Center for Religious and Crosscultural Studies, Sekolah Pascasarjana, Universitas Gadjah Mada, 2010), h. 31.

${ }^{13}$ J. B. Banawiratma, Zainal Abidin Bagir (ed.), Dialog Antar Umat Beragama, h. 39.

${ }^{14}$ Delapan elemen komunikasi versi Taylor: 1. Sumber (source), 2. Stimulus yang diterima dari sumber (stimulus received from the source), 3. Penerima (receiver), 4. Tanggapan pancaindra (Sensory receptors), 6. Interpretasi dan respon terhadap sensasi (the receiver's interpretations and responses to the sensation), dan 7. Gangguan komunikasi (noice). Taylor et al, "The Classic Human Communication Model", dalam Anton Karl kozlovic, "A Human Communication Approach to Interreligious Dialogue,” Volume 16, Number I 49 The Flinders University of South Australia. dalam https://openjournals.library.sydney.edu.au/index.php/ARSR/article/view/8987 Diakses 06 Oktober 2018. 
Dialog sangat penting untuk mencapai perdamaian. Di kalangan Katholik, dialog dengan kaum Yahudi dan Muslim bertujuan mengikis rasa permusuhan serta menumbuhkan sikap saling memahami, saling memaklumi, dan saling menghormati. ${ }^{15}$ Dialog sudah sering dilakukan namun biasanya hanya melibatkan tokoh dari berbagai agama untuk membicarakan persoalan yang muncul di tengah-tengah masyarakat, terutama kalau terjadi konflik bernuansa agama. Bentuk dakwah ini terkadang menyisakan persoalan yakni kesepakatan di level atas sudah tercapai akan tetapi karena tidak mencapai level grassroot sehingga konflik lanjutan muncul kembali. Kedepannya, dialog ini hendaknya tidak hanya dilakukan di saat terjadi konflik seperti biasanya. Akan tetapi dialog dilakukan dalam rangka membantu pemerintah dalam melaksanakan program-programnya di tengah-tengah masyarakat.

Di mata Sumanto al-Qurtubi, dalam konteks relasi antar-agama, khususnya Muslim-Kristen, dialog menjadi jalan terbaik untuk membangun hubungan harmonis dan toleran kedua kelompok agama ini. Pandangan ini didasarkan alasan dan argumen berikut: ${ }^{16} 1$. Dialog tidak didasarkan pada kalah menang, semuanya pemenang, karena setiap agama memiliki keunikan dan keistimewaan yang tidak bisa dihakimi orang lain yang tidak pernah "mengalami sendiri dari dalam." 2. Dialog mencari kelebihan dan kekuatan masing-masing pihak untuk dijadikan sebagai medium kerjasama yang produktif dan kreatif. 3. Perbedaan dijadikan sebagai "medium" belajar untuk saling memahami masing-masing agama yang bisa dijadikan sarana membangun "common ground" yang postif dan konstruktif, yang didasari spirit saling menghargai dan menghormati masing-masing agama. 4. Ada komitmen yang tulus dari masing-masing pihak untuk membangun hubungan antar agama yang dinamis. 5. Dialog bertumpu pada kerendahan hati, mengakui dan menghargai pendapat pengikut agama lain, mengakui kebenaran agamanya, sehingga timbul sikap terbuka atau inklusif.

\section{Dakwah Aksi}

Dakwah aksi diperlukan terutama dalam pembinaan masyarakat pasca konflik. Dalam kondisi ini dakwah bentuk aksi nyata sangat diperlukan, misalnya dalam melakukan rekonsiliasi pasca konflik. Termasuk dalam dakwah aksi antara lain perbaikan fasilitas yang rusak akibat konflik,

${ }^{15}$ Syamsuddin Arif, "Interfaith Dialog dan Hubungan Antar Agama dalam Perspektif Islam," Jurnal Tsaqafah, Vol. 6 No. 1 April 2010: 147-165 dalam https://ejournal.unida.gontor.ac.id/index/php/tsaqafah/article/view/143/134 Diakses 11 Mei 2019.

${ }^{16}$ Sumanto al-Qurtubi, "Dialog, Bukan Debat Kristen-Muslim" dalam https://www.liputan6.com/news/read/2923215/opini-dialog-bukan-debat-kristenmuslim Diakses 23 Juli 2018. 
pertandingan olah raga dan seni dengan melibatkan pemain dari kelompokkelompok yang bertikai sebelumnya, dan pembuatan film pendek bertemakan kepedulian yang melibatkan aktor atau pemain dari kedua pihak yang terlibat dalam konfik. Dai-dai kita, termasuk lembaga-lembaga dakwah yang sangat banyak di Indonesia, 50 lembaga lebih banyak berkutat dalam dakwah mimbar. Dakwah dalam konteks lain belum mendapatkan perhatian serius, termasuk dakwah aksi ini. Agak ironis memang karena di satu sisi secara teoretis dan retoris kita sering mendengungkan semboyan " $d a$ 'wat bi al-hâl lebih efektif ketimbang da 'wat bi al-lisân," namun di sisi lain justeru da 'wat bi al-lisân inilah yang paling banyak dilakukan.

\section{Dakwah Pendampingan}

Program pendampingan di Indonesia terkadang menjadi pilihan dalam menunjang program utama. Di saat suatu program yang diluncurkan pemerintah dan ternyata menemui banyak hambatan. Demkikian pula ketika masyarakat mendapatkan kesulitan dalam mengikuti program tertentu karena berbagai kendala. Dalam kondisi seperti ini biasanya pemerintah melalui kementerian terkait mendisain program pendampingan. Penulis pernah terlibat dalam program pendampingan masyarakat tani, sebagai instruktur. Tenagatenaga pendamping yang sudah dilatih diterjunkan ke tengah-tengah masyarakat, tinggal bersama masyarakat selama beberapa bulan. Tenaga pendamping membantu masyarakat dalam proses mendapatkan pinjaman dari bank untuk modal usaha pertanian, menjadi penghubungan antara petani dengan pihak pertanian. Membantu mereka agar dapat dengan mendapatkan pupuk, bibit dan penyemprotan.

Dakwah pendampingan ini diterapkan pada segmen masyarakat tertentu yang menjadi fokus perhatian. Dakwah ini sangat perlu bagi kelompok muallaf, karena mereka memerlukan perhatian khusus, dukungan dan pemberdayaan agar mereka mampu memertahankan dan memerkokoh iman mereka. Agaknya menjadi tanggung jawab umat Islam untuk memerhatikan keidupan mereka, tidak hanya dalam spiritual, melainkan juga sosial, ekomomi dan pendidikan. Dakwah ini antara lain dapat dilakukan pada kelompok remaja, khususnya remaja masjid. Dakwah pendampingan terhadap remaja bertujuan agar mereka menjadi generasi muda yang baik, yaitu yang beriman, saleh, berilmu, memiliki skill dan berakhlaq mulia. ${ }^{17}$

Untuk kasus dakwah relasi agama ini dakwah dalam bentuk pendampingan bisa menjadi alternatif. Terhadap masyarakat yang rentan

\footnotetext{
${ }^{17}$ Deddy Susanto, "Pemberdayaan dan Pendampingan Remaja Mesjid melalui Pelatihan Manajemen Mesjid, Organisasi dan Kepemimpinan," https://ejournal.unisnu.ac.id/JKIN/article/download (11 Mei 2019)
} 
terhadap konflik hendaknya diterapkan dakwah pendampingan. Dalam dakwah pendampingan, dai-dai berfungsi mengawal dan mendampingi masyarakat dalam interaksinya dengan masyarakat lain dengan latar belakang keyakinan yang berbeda. Di samping dakwah pendampingan juga diperlukan terutama di saat terjadi kegiatan politik seperti pemilihan dalam berbagai bentuk dan levelnya. Sering terjadi konflik yang dipicu oleh arus gelombang politik kemudian diberi bumbu agama sehingga terlihat seakan-akan konflik agama, padahal berlatarbelakang politik. Masyarakat seperti ini patut mendapatkan pendampingan agar tidak mudah terprovokasi.

\section{SIMPULAN}

Dakwah relasi agama merupakan suatu keniscayaan. Dakwah ini sebagai respon atas sikap para pemeluk agama untuk saling memahami, mengenal lebih jauh agar dapat saling menghargai. Sejalan dengan ini teks-teks keagamaan juga mulai didekati dengan pendekatan modern sesuai dengan teori-teori relasi agama. Hanya saja mungkin upaya tersebut tidak dilandasi dengan kegtulusan sehingga kecurigaan muncul. Dialog juga sepertinya tidak banyak membuahkan hasil karena juga dilandasi ketidaktulusan. Ada agenda tersembunyi di balik dialog, tetapi dikemas dengan misi keagamaan tertentu. Secara retoris selalu didengungkan pelepasan truth claim, tapi kenyataannya tetap saja mewarnai gelanggang dakwah keagamaan. Pluralisme sesungguhnya dimaksudkan untuk mengikis fanatisme beragama, namun konsekuensinya menganggap agama semuanya sama. Setelah banyak orang terhipnotis dengan gagasan ini, justeru kalangan non-Muslim menegaskan bahwa pada hakekatnya agama-agama tidaklah sama karena agama Kristen memiliki nilai plus ketimbang agama-agama lain. Di sisi lain gelombang perkembangan Islam di Barat semakin pesat yang membuat petinggi agama lain khawatir sehngga mereka menyiapkan berbagai strategi untuk menghalau. Muncullah pelabelan Islam sebagai agama radikal, agama kekerasan, agama terror. Ironisnya sikap ini merambah ke berbagai kawasan, dan melibatkan bukan hanya petinggi agama tetapi juga kalangan awam. Akibatnya, seperti dapat dilihat di media sosial semakis marak penistaan agama yang dilakukan non-Muslim. Kalau penistaan ini tidak dihadapi dengan bijak maka akan memicu konflik horizontak bernuansa SARA, dengan berbagai akibatnya. Dengan fakta ini terlihat bahwa dakwah relasi agama menemukan momentunnya, dengan catatan pelaksanaannya harus profesional.

\section{DAFTAR PUSTAKA}

\section{Referensi Cetak}

Abdullah, Amin (2015). "System Approach" dalam Suhadi (ed.), COSTLY TOLERANCE: Tantangan Baru Muslim-Kristen di Indonesia dan 
Belanda.Yogyakarta: CRCS (Center for Religious and Cross-Cultural Studies), Program Studi Sgama dan Lintas Agama. Sekolah Pascasarjana Lintas Disiplin, Universitas Gadjah Mada.

Ali, Muhammad (2003). "Hermeneutika Kontekstual dan Pluralisme Agama" dalam TEOLOGI PLURALIS-MULTIKULTURAL: Menghargai Kemajemukan Menjalin Kebersamaan. Jakarta: Penerbit Buku Kompas.

Banawiratma J. B. (2010), Zainal Abidin Bagir (ed.), Dialog Antar Umat

Beragama (Gagasan dan Praktik di Indonesia). Yogyakarta: Program Studi Agama dan Lintas Budaya, Center for Religious and Cross-cultural Studies, Sekolah Pascasarjana, Universitas Gadjah Mada.

Hugh Goddard (1995), Christian and Muslim: From Double Standard to Mutual Understanding. Richmond, Surrey: Curson Press.

Katu, Samiang. "Penyuluh Agama dan Pembumian Al-Qur'an," Jurnal alAdyaan, Vol. I Nomor 2, Desember 2015: 1-21.

Syamsuddin, Sahiron (2015). "Ma 'na Cum Maghzâ" dalam Suhadi (ed.), COSTLY TOLERANCE: Tantangan Baru Muslim-Kristen di Indonesia dan Belanda. Yogyakarta: CRCS (Center for Religious and Cross-Cultural Studies), Program Studi Sgama dan Lintas Agama. Sekolah Pascasarjana Lintas Disiplin, Universitas Gadjah Mada.

Shihab, M. Quraish (2000). Tafsir al-Mishbah: Pesan, Kesan dan Keserasian AlQur'an, Vol.1. Jakarta:Penerbit Lentera Hati.

Sinclair, John (ed.) (1987). Collins Cobuild English Language Dictionary. London: William Collins Sons and Co. Ltd.

\section{Referensi Online}

Arif, Syamsuddin. "Interfaith Dialog dan Hubungan Antar Agama dalam Perspektif Islam," Jurnal Tsaqafah, Vol. 6 No. 1 April 2010: 147-165 dalam https://ejournal.unida.gontor.ac.id/index/php/tsaqafah/article/view/143/134 Diakses 11 Mei 2019.

al-Qurtubi, Sumanto. "Dialog, Bukan Debat Kristen-Muslim" dalam https://www.liputan6.com/news/read/2923215/opini-dialog-bukan-debat-kristenmuslim Diakses 23 Juli 2018. 
Susanto, Deddy. "Pemberdayaan dan Pendampingan Remaja Mesjid melalui Pelatihan Manajemen Mesjid, Organisasi dan Kepemimpinan," dalam https://ejournal.unisnu.ac.id/JKIN/article/download Diakses 11 Mei 2019.

Taylor et al, "The Classic Human Communication Model", dalam Anton Karl kozlovic, "A Human Communication Approach to Interreligious Dialogue," Volume 16, Number I 49 The Flinders University of South Australia. Dalam https://openjournals.library.sydney.edu.au/index.php/ARSR/article/view/8987 Diakses 06 Oktober 2018. 